\title{
Synthesis, characterization and stability properties of Cl-bearing hydrotalcite-pyroaurite solids
}

\author{
By K. Rozov*, H. Curtius, A. Neumann and D. Bosbach \\ Forschungszentrum Jülich, Institut für Energie- und Klimaforschung (IEK-6), 52425 Jülich, Germany \\ (Received January 31, 2012; accepted in final form July 4, 2012) \\ (Published online November 19, 2012)
}

Secondary phases / Layered double hydroxides /

Hydrotalcites / Thermodynamic properties

\begin{abstract}
Summary. A layered double hydroxides (LDH) hydrotalcite-pyroaurite solid solution series $\left(\mathrm{Mg}_{1-x} \mathrm{Fe}(\mathrm{II})_{x}\right)_{3} \mathrm{Al}_{1} \mathrm{Cl}_{1}$. $n \mathrm{H}_{2} \mathrm{O}$ with variable $x \mathrm{Fe}_{\text {solid }}=\mathrm{Fe}^{2+} /\left(\mathrm{Fe}^{2+}+\mathrm{Mg}^{2+}\right)$ iron mole fractions were studied in co-precipitation experiments at $T=25,40,45,50,55$ and $60{ }^{\circ} \mathrm{C}$ and $\mathrm{pH}=10.00 \pm 0.05$. The compositions of the solids and reaction solutions were determined using ICP-OES, EDX ( $\mathrm{Mg}, \mathrm{Al}, \mathrm{Fe})$ and TGA techniques $\left(\mathrm{Cl}^{-}, \mathrm{OH}^{-}, \mathrm{H}_{2} \mathrm{O}\right)$. Powder X-ray diffraction was applied for phase identification and determination of unit-cell parameters $a_{\mathrm{o}}=b_{\mathrm{o}}$ and $c_{\mathrm{o}}$ from Bragg evaluation. Syntheses products containing $x \mathrm{Fe}_{\text {solid }}>0.13$ display additional $\mathrm{X}$-ray patterns attributed to the mixture of iron oxides and hydroxides. On the other side, precipitates with $0 \leq x \mathrm{Fe}_{\text {solid }} \leq 0.13$ show only X-ray reflexes typical for pure $\mathrm{LDH}$ compositions. Moreover, in this case unit-cell parameters $a_{\mathrm{o}}=b_{\mathrm{o}}$ as a function of $x \mathrm{Fe}_{\text {solid }}$ follow Vegard's law corroborating the existence of a continuous solid solution series. TGA data demonstrated the temperatures at which interlayer $\mathrm{H}_{2} \mathrm{O}$ molecules and $\mathrm{Cl}^{-}$-anions are lost, and at which temperatures dehydroxylation of brucite-like layer occurs. Based on detailed analyses of TGA curves it was established that the increase of $x \mathrm{Fe}_{\text {solid }}$ does not result in a visible change of the thermal stability of hydrotalcite-pyroaurite solids. From the chemical analyses of both the solids and the reaction solutions after syntheses, preliminary Gibbs free energies of formation were estimated by using GEMS-PSI code package. Values of $G_{\mathrm{f}}^{\circ}($ Hydrotalcite $)=-3619.04 \pm 15.27 \mathrm{~kJ} / \mathrm{mol}$ and $G_{\mathrm{f}}^{\circ}($ Pyroaurite $)=-2703.61 \pm 191.93 \mathrm{~kJ} / \mathrm{mol}$ were found at $298.15 \mathrm{~K}$. A comparison of our estimate with $G_{\mathrm{f}}^{\circ}$ value $-3746.90 \pm 11.00 \mathrm{~kJ} / \mathrm{mol}$ for $\mathrm{CO}_{3}{ }^{2-}$-bearing hydrotalcite presented in our previous studies, denotes the effect of intercalated anion on the aqueous solubilities of $\mathrm{LDH}$ when Cl-containing solids have to be more soluble than $\mathrm{CO}_{3}{ }^{2-}$ bearing substances. Estimation of the standard molar entropy of the hydrotalcite end-member by applying Helgeson's methods and using results of co-precipitation experiments at variable temperatures let us to conclude that derivation of more precise $S_{\mathrm{f}}^{\circ}$ values would require calorimetric measurements.
\end{abstract}

\footnotetext{
*Author for correspondence (E-mail: K.Rozov@fz-juelich.de).
}

\section{Introduction}

The disposal of radioactive waste (especially, spent fuel elements) in natural geological environments calls for the development of new radionuclide-binding materials. These materials have to: (1) be physically and chemically stable at repository conditions for a long enough time to ensure that radioactive decay will greatly reduce the level of activity and (2) prevent the migration of different (i.e., cationic and anionic) radioactive compounds and their decay products from deep geological conditions to the biosphere. Layered double hydroxide phases (LDHs) or hydrotalcite-like solids are of interest to these studies due to their ability to retain very wide range of different cations (like, $\mathrm{Li}^{+}, \mathrm{Ba}^{2+}, \mathrm{Mg}^{2+}$, $\mathrm{Fe}^{2+}, \mathrm{Ni}^{2+}, \mathrm{Al}^{3+}, \mathrm{Fe}^{3+}, \mathrm{Cr}^{3+}, \mathrm{Ga}^{3+}, \mathrm{Sc}^{3+}, \mathrm{Zr}^{4+}$, etc. ) [1-7] and especially due to their anion-exchange properties (substitutions of $\mathrm{I}^{-}, \mathrm{Br}^{-}, \mathrm{Cl}^{-}, \mathrm{OH}^{-}, \mathrm{CO}_{3}{ }^{2-}, \mathrm{SO}_{4}{ }^{2-}, \mathrm{Fe}(\mathrm{CN})_{6}{ }^{4-}$, carboxylates, sulfonates or dicarboxylates $\mathrm{C}_{n} \mathrm{H}_{2 n}\left(\mathrm{CO}_{2}{ }^{-}\right)_{2}$, etc.) [8-15]. The anion-exchange properties of $\mathrm{LDHs}$ with general formula $\left[\mathrm{M}^{\mathrm{II}}{ }_{(1-x)} \mathrm{M}^{\mathrm{III}}{ }_{(x)}(\mathrm{OH})_{2}\right]^{x+}\left[\mathrm{A}_{x / y}^{y} \cdot n \mathrm{H}_{2} \mathrm{O}\right]^{x-}$ result directly from their structure which is composed of positively charged brucite-like layers (the first set brackets) and intercalated anions which are accompanied by molecules of water (the second set of brackets in the formula). This means that LDHs can be considered especially as potential buffer materials in multibarrier systems for retention of mobile, soluble and long-lived radioactive anions (like, ${ }^{14} \mathrm{C},{ }^{129} \mathrm{I},{ }^{36} \mathrm{Cl},{ }^{79} \mathrm{Se}$ etc.) [16]. However, the understanding of the retention properties, behavior of LDHs in aqueous environment and finally, applying these substances for geochemical modeling at conditions of nuclear repositories are hampered by scarce information on their thermodynamic and solubility properties. The problem of retrieving thermodynamic data and predicting stability of LDHs have been recently touched only in a few studies $[8,17-20]$. This work on the synthesis, characterization of a particular case of big LDH family, namely, chloride-bearing hydrotalcite $(\mathrm{Htlc}) \mathrm{Mg}_{3} \mathrm{Al}(\mathrm{OH})_{8} \mathrm{Cl} \cdot n \mathrm{H}_{2} \mathrm{O}$ - pyroaurite (Pyr) $\mathrm{Fe}(\mathrm{II})_{3} \mathrm{Al}(\mathrm{OH})_{8} \mathrm{Cl} \cdot n \mathrm{H}_{2} \mathrm{O}$ solids because they have been identified as characteristic secondary phase components in corrosion products under repository conditions of disposed nuclear fuel elements [4,21]. Using various experimental techniques (X-ray powder diffraction, infrared spectroscopic measurements, thermogravimetric 
analysis, scanning electron microscopy, energy dispersive $\mathrm{X}$-ray spectroscopy), the primary objective was to ascertain the presence of a continuous solid solution series between hydrotalcite and pyroaurite (i.e., isostructural substitution of $\mathrm{Mg}$ by $\mathrm{Fe}(\mathrm{II}))$. The next objectives were to quantify the standard Gibbs free energies and entropies of formation with the help of thermodynamic modeling [22] based on the chemical analysis of solid and liquid phases at equilibrium and to provide temperature corrections for thermodynamic properties of solids by using data from synthesis experiments at different $\left(25,40,45,50,55\right.$ and $\left.60{ }^{\circ} \mathrm{C}\right)$ temperatures.

\section{Materials and methods}

\subsection{LDH synthesis}

Samples of hydrotalcite-pyroaurite solids with varying mole fractions of iron(II) $x \mathrm{Fe}_{\text {solid }}=\mathrm{Fe}^{2+} /\left(\mathrm{Fe}^{2+}+\mathrm{Mg}^{2+}\right)$ were synthesized by a co-precipitation method at $T=25,40,45,50$, 55 and $60{ }^{\circ} \mathrm{C}$ and $\mathrm{pH}=10.00 \pm 0.05$. The syntheses were performed under argon gas flow by slow addition (at a rate $0.2-0.3 \mathrm{~mL} / \mathrm{min}$ ) of $50 \mathrm{~mL}$ degassed metal-chloride solution with $\left(\mathrm{Mg}^{2+}+\mathrm{Fe}^{2+}\right) / \mathrm{Al}^{3+}=3.0 \pm 0.1$ into a reactor vessel containing $350 \mathrm{~mL}$ of boiled MilliQ water under stirring. To maintain $\mathrm{pH}=10.00 \pm 0.05,2 \mathrm{M} \mathrm{NaOH}$ solution was added simultaneously into the reactor using an automated titrator 736 GP TITRINO. The overall reaction of synthesis can be described as:

$$
\begin{aligned}
& (3-3 x) \cdot \mathrm{MgCl}_{2}+\mathrm{AlCl}_{3}+3 x \cdot \mathrm{FeCl}_{2}+8 \mathrm{NaOH}+n \mathrm{H}_{2} \mathrm{O} \\
& =\left(\mathrm{Mg}_{1-x} \mathrm{Fe}_{x}\right)_{3} \mathrm{Al}_{1}(\mathrm{OH})_{8} \mathrm{Cl}_{1} \cdot n \mathrm{H}_{2} \mathrm{O}+8 \mathrm{NaCl}
\end{aligned}
$$

After the addition step, the stirring was continued for $24 \mathrm{~h}$ under controlled $\mathrm{pH}(\mathrm{pH}=10.00 \pm 0.05)$ and needed temperature. The precipitate and supernatant liquid were then separated by using $0.22 \mu \mathrm{m}$ MILLEX $^{\circledR}$ GP filters. The formed solid was washed three times by boiled MilliQ water and dried in a desiccator for $72 \mathrm{~h}$.

\subsection{Chemical analyses of solid and liquid phases}

\subsubsection{ICP-OES analyses}

The contents of $\mathrm{Mg}, \mathrm{Fe}, \mathrm{Al}$ and $\mathrm{Na}$ in the solids and supernatant liquids were determined by ICP-OES method using TJA-IRIS ${ }^{\mathrm{TM}}$ instrument. The supernatant solutions were analyzed after acidifying with drops of $8 \mathrm{M} \mathrm{HNO}_{3}$. The solid samples were analyzed after dissolving in $2 \mathrm{M}$ $\mathrm{HNO}_{3}$. Solutions of internal standards were prepared from $\mathrm{MgCl}_{2} \cdot 6 \mathrm{H}_{2} \mathrm{O}, \mathrm{FeCl}_{2} \cdot 4 \mathrm{H}_{2} \mathrm{O}, \mathrm{AlCl}_{3} \cdot 6 \mathrm{H}_{2} \mathrm{O}$ and $\mathrm{NaCl}$ chemicals $\left(\right.$ Merck $\left.^{\circledR}\right)$.

\subsubsection{Photometric analyses}

Chloride anions in the product liquid phase and in synthesized solids were analyzed photometrically (spectrophotometer CADAS 100). The solid samples were analyzed after dissolving in $2 \mathrm{M} \mathrm{HNO}_{3}$. The supernatant liquids were measured after dilution $(1: 10$ and $1: 100)$ with degassed MilliQ water. Solutions of $\mathrm{NaCl}$ were used for the preparation of internal standards.

\subsection{Powder X-ray diffraction (PXRD)}

The powder X-ray diffraction measurements were applied for structural characterization of the synthesized solids with respect to long-range ordering by using a 3003 TT (General Electric) diffractometer (Bragg-Brentano geometry). No internal standards for possible specimen displacement were used. The samples were measured from 5 to $85^{\circ} 2 \Theta$ with a step size of $0.02^{\circ} 2 \Theta$ and a measuring time of $15 \mathrm{~s}$ per step. The cell parameters were calculated from the Bragg equation and using relation between indexed $d_{h k l}$ distances and the lattice unit-cell parameters for hexagonal symmetry based on the first 4 reflections: (003), (006), (012), and (015).

\subsection{Infrared spectroscopy}

Infrared spectra of precipitates were acquired using an FTIR Bruker Equinox spectrometer in order to identify the interlayer composition (anions and water-molecules). Pellet samples were prepared by weighing approximately $200 \mathrm{mg} \mathrm{KBr}$ powder $\left(\right.$ Merck $\left.^{\circledR}\right)$ together with approximately $2 \mathrm{mg}$ of each sample ( $1 \%$ by mass) which were finally mixed and pressed in $20 \mathrm{~mm}$ disks. Spectra were recorded in the wavenumber interval from 800 to $4000 \mathrm{~cm}^{-1}$.

\subsection{Thermogravimetric analyses (TGA)}

TGA-DSC was carried out in order to determine the contents of interlayer water, hydroxyl groups and chloride-anions in solids. Measurements were performed on a Netzsch STA 449 C Jupiter ${ }^{\mathrm{TM}}$ instrument. The weight loss of the solids was analyzed from $25^{\circ} \mathrm{C}$ to $1000{ }^{\circ} \mathrm{C}$ with a heating rate of $10^{\circ} \mathrm{C} / \mathrm{min}$, under a nitrogen flow.

\subsection{Scanning electron microscopy (SEM) and energy dispersive X-ray spectroscopy (EDX)}

In order to investigate the morphology of synthesized crystallites the low-pressure scanning electron microscopy (SEM) photographs were taken with a Quanta 200 microscope. Examinations were performed at a pressure of $70 \mathrm{~Pa}$. Additional quantitative chemical analyses of solids (content of $\mathrm{Mg}, \mathrm{Fe}, \mathrm{Al}, \mathrm{Cl}, \mathrm{C}, \mathrm{O}$ ) and information about chemical homogeneity of precipitates were carried out with energy dispersive X-ray spectroscopy (EDX) an Apollo X Silicon Drift Detector from $\mathrm{EDAX}^{\mathrm{TM}}$, at a voltage of $20 \mathrm{kV}$.

\section{Thermodynamic modeling}

\subsection{Estimation of Gibbs free energies}

Gibbs free energies of formation of the solids at $T=25,40$, $45,50,55$ and $60^{\circ} \mathrm{C}$ were estimated under assumption of the thermodynamic equilibrium between synthesized solids and liquid phases after synthesis experiments. This assumption was used because our previous co-precipitation and long-term ( $>140$ day) dissolution tests with $\mathrm{CO}_{3}{ }^{2-}$-bearing hydrotalcites [19] had clearly shown a non-significant oversaturation degree in aqueous solutions after analogous syntheses. Therefore, in the present study the following scheme 
of $G_{\mathrm{f}}^{\circ}(298)$ estimations has been applied: 1) using results of chemical analyses the speciation of aqueous phases has been modeled in order to calculate activities and chemical potentials of all relevant components (i.e., $\mathrm{Mg}^{2+}, \mathrm{Fe}^{2+}, \mathrm{Al}^{3+}$, $\mathrm{OH}^{-}, \mathrm{Cl}^{-}$). For this purpose we used the Gibbs free energy minimization software GEM-Selektor [22] with builtin NAGRA-PSI and SUPCRT/Slop98 chemical thermodynamic database $[23,24]$; 2) on the second step, we applied the statement of the thermodynamic equilibrium which says that: Gibbs free energy of the system at the equilibrium is minimum, and chemical potentials of the components at equilibrium are the same in each phase. This permitted the determination of the Gibbs free energies from chemical potentials of solutes and from the stoichiometric coefficients in Tables 3 and 4 according to:

$$
\begin{aligned}
G_{\mathrm{f}}^{\circ}(\mathrm{Htlc}-\mathrm{Pyr})= & a \mu\left(\mathrm{Mg}^{2+}\right)+b \mu\left(\mathrm{Fe}^{2+}\right)+c \mu\left(\mathrm{Al}^{3+}\right) \\
& +d \mu\left(\mathrm{OH}^{-}\right)+e \mu\left(\mathrm{Cl}^{-}\right)
\end{aligned}
$$

where $a-e$ : stoichiometric coefficients; $\mu$ - chemical potentials, calculated from the supernatant liquid composition.

\subsection{Estimation of absolute molar entropies of formation}

We estimated the absolute molar entropies at $298 \mathrm{~K}$ and 1 bar in order to provide temperature and pressure corrections for Gibbs free energies of synthesized hydrotalcite solids. This has been done applying two different approaches: 1) the method of Helgeson [25] (see below); and 2) based on results of hydrotalcite syntheses at various temperatures $\left(25,40,45,50,55\right.$ and $\left.60^{\circ} \mathrm{C}\right)$.

By applying the approach of Helgeson [25] we considered the absolute molar entropy $(236.66 \mathrm{~J} / \mathrm{mol} \mathrm{K})$ of the carbonate-bearing hydrotalcite $\mathrm{Mg}_{3} \mathrm{Al}(\mathrm{OH})_{8}\left(\mathrm{CO}_{3}\right)_{0.5}$ investigated in co-precipitation and dissolution experiments at ambient $\left(23 \pm 2{ }^{\circ} \mathrm{C}, 1\right.$ bar $)$ conditions [19]. Then, we constructed the hypothetical anion-exchange reaction between carbonate-containing composition and chloridebearing solid:

$$
\begin{aligned}
& \mathrm{Mg}_{3} \mathrm{Al}(\mathrm{OH})_{8}\left(\mathrm{CO}_{3}\right)_{0.5}+\mathrm{Cl}^{-}{ }_{(\mathrm{aq})} \leftrightarrow \\
& \mathrm{Mg}_{3} \mathrm{Al}(\mathrm{OH})_{8} \mathrm{Cl}_{1}+0.5 \mathrm{CO}_{3}{ }^{2-}{ }_{(\mathrm{aq})}
\end{aligned}
$$

Since the reactant and product solids have similar structures, the approximation can be made (following [25]) that $\Delta_{\mathrm{r}} S^{\circ}$ is zero. This assumption and the data on the entropies of $\mathrm{Cl}^{-}$ and $\mathrm{CO}_{3}{ }^{2-}$ aqueous species $(56.735$ and $-49.999 \mathrm{~J} / \mathrm{mol} \mathrm{K}$, respectively [24]) allowed to estimate the absolute molar entropy of the chloride-bearing hydrotalcite substance.

The experimental method to evaluate the absolute molar entropy of hydrotalcite was based on the temperature dependence of the molar Gibbs free energies of synthesized hydrotalcites. In the first step, we used results of chemical analyses of hydrotalcite solids and corresponding supernatant liquids from syntheses at different temperatures $(25,40,45,50,55$ and $60{ }^{\circ} \mathrm{C}$ ) and obtained values of Gibbs free energies of hydrotalcite according to the scheme described in Sect. 3.1. Then we constructed the reaction of hydrotalcite decomposition to simple aqueous species:

$$
\begin{aligned}
\mathrm{Mg}_{3} \mathrm{Al}(\mathrm{OH})_{8} \mathrm{Cl}= & 3 \mathrm{Mg}^{2+}{ }_{(\mathrm{aq})}+\mathrm{Al}^{3+}{ }_{(\mathrm{aq})}+8 \mathrm{OH}^{-}{ }_{(\mathrm{aq})} \\
& +\mathrm{Cl}^{-}{ }_{(\mathrm{aq})},
\end{aligned}
$$

and calculated the corresponding equilibrium constants at $T=25,40,45,50,55$ and $60^{\circ} \mathrm{C}$ using free energies $\left(G_{\mathrm{f}, \mathrm{T}}\right)$ of simple aqueous species $\left(\mathrm{Mg}^{2+}, \mathrm{Al}^{3+}, \mathrm{OH}^{-}, \mathrm{Cl}^{-}\right)$at given temperatures $T$, taken from NAGRA/PSI database [23] and using Eq. (5):

$$
\begin{aligned}
\Delta_{\mathrm{r}} G(T)= & 3 G_{\mathrm{f}, \mathrm{T}}\left(\mathrm{Mg}^{2+}{ }_{(\mathrm{aq})}\right)+G_{\mathrm{f}, \mathrm{T}}\left(\mathrm{Al}^{3+}{ }_{(\mathrm{aq})}\right) \\
& +8 G_{\mathrm{f}, \mathrm{T}}\left(\mathrm{OH}^{-}{ }_{(\mathrm{aq})}\right)+G_{\mathrm{f}, \mathrm{T}}\left(\mathrm{Cl}^{-}{ }_{(\mathrm{aq})}\right)-G_{\mathrm{f}, \mathrm{T}}(\mathrm{Htlc}) \\
= & -R T \ln K
\end{aligned}
$$

Next, we used the Van't Hoff equation (Eq. 6) in order to calculate the enthalpy effect of this reaction at $298.15 \mathrm{~K}$ and to find the standard enthalpy of hydrotalcite phase:

$$
\ln \left(\frac{K_{T}}{K_{298.15}}\right)=-\frac{\Delta_{\mathrm{r}} H(298.15 \mathrm{~K})}{R} \times\left[\frac{1}{T}-\frac{1}{298.15}\right],
$$

where $K_{\mathrm{T}}$ and $K_{298.15}$ - the equilibrium constants of Eq. (4) at given temperature $T$ and $298.15 \mathrm{~K}$, respectively; $\Delta_{\mathrm{r}} H$ $(298.15 \mathrm{~K})$ - the enthalpy effect of reaction at $298.15 \mathrm{~K}$. Finally, in order to calculate the entropy change in Eq. (4) and the absolute molar entropy of hydrotalcite, the fundamental relation defining the important thermodynamic functions (Gibbs free energy, entropy and enthalpy) has been applied:

$$
\Delta_{\mathrm{r}} S=\left(\Delta_{\mathrm{r}} H-\Delta_{\mathrm{r}} G\right) / T
$$

\section{Results}

\subsection{Compositions of solids and liquid phases after co-precipitation experiments}

The compositions of liquid and solid phases after coprecipitation experiments are provided in Tables 1-4.

Table 1. Compositions of aqueous solutions $(\mathrm{pH}=10.00 \pm 0.05)$ after hydrotalcite-pyroaurite synthesis at $25^{\circ} \mathrm{C}$

\begin{tabular}{lrrlrrr}
\hline $\begin{array}{l}\text { Approxi- } \\
\text { mate mole } \\
\text { fraction } \\
\left(x \mathrm{Fe}_{\text {solid }}\right)\end{array}$ & $\mathrm{Mg}$ & $\begin{array}{c}\mathrm{Al} \\
(\mu \mathrm{mol} / \mathrm{kg})\end{array}$ & & $\mathrm{Fe}$ & $\begin{array}{c}\mathrm{Na} \\
(\mathrm{mmol} / \mathrm{kg})\end{array}$ & $\begin{array}{c}\mathrm{Cl} \\
(\mathrm{Mg}+\mathrm{Fe}) / \mathrm{Al} \\
\text { in aqueous } \\
\text { phase }\end{array}$ \\
\hline 0.000 & 70.70 & 1.11 & below DL & 90.16 & 111.70 & 63.69 \\
0.033 & 254.00 & 1.11 & below DL & 89.23 & 99.85 & 228.83 \\
0.067 & 29.50 & 7.49 & below DL & 90.16 & 102.95 & 3.94 \\
0.100 & 33.33 & 13.48 & below DL & 94.07 & 99.85 & 2.47 \\
0.133 & 95.60 & 11.24 & below DL & 98.02 & 102.95 & 8.51 \\
0.500 & 35.00 & 435.02 & below DL & 95.07 & 105.20 & 0.08 \\
\hline
\end{tabular}

Table 2. Compositions of aqueous solutions $(\mathrm{pH}=10.00 \pm 0.05)$ after hydrotalcite syntheses at $25,40,45,50,55$ and $60{ }^{\circ} \mathrm{C}$.

\begin{tabular}{lccrrr}
\hline$T\left({ }^{\circ} \mathrm{C}\right)$ & $\begin{array}{c}\mathrm{Mg} \\
(\mu \mathrm{mol} / \mathrm{kg})\end{array}$ & $\begin{array}{c}\mathrm{Na} \\
(\mathrm{mmol} / \mathrm{kg})\end{array}$ & $\begin{array}{c}\mathrm{Cl} \\
\text { in } / \mathrm{Al} \\
\text { aqueous } \\
\text { phase }\end{array}$ \\
\hline 25 & & & & & \\
40 & 666.00 & 1.12 & 100.25 & 122.42 & 594.64 \\
45 & 129.00 & 1.13 & 97.58 & 93.65 & 114.16 \\
50 & 143.00 & 1.43 & 96.87 & 92.23 & 100.00 \\
55 & 15.00 & 1.61 & 95.84 & 104.36 & 9.32 \\
60 & 83.70 & 1.12 & 95.50 & 102.11 & 74.73 \\
& 21.5 & 3.03 & 98.00 & 110.29 & 7.10 \\
\hline
\end{tabular}


Table 3. Stoichiometric formulae of hydrotalcite-pyroaurite solids synthesized at $25^{\circ} \mathrm{C}$ and $\mathrm{pH}=10.00 \pm 0.05$.

\begin{tabular}{llc}
\hline $\begin{array}{l}\text { Mole frac- } \\
\text { tion of iron } \\
\text { in solids }\end{array}$ & $\begin{array}{r}\left(\mathrm{Mg}^{2+}+\mathrm{Fe}^{2+}\right) / \\
\mathrm{Al}^{3+} \text { in } \\
\text { solid phase }\end{array}$ \\
\hline 0.000 & $\mathrm{Mg}_{3} \mathrm{Al}_{1.030}(\mathrm{OH})_{8.187} \mathrm{Cl}_{0.903} \cdot 2.37 \mathrm{H}_{2} \mathrm{O}$ & 2.913 \\
0.029 & $\mathrm{Mg}_{2.912} \mathrm{Fe}_{0.088} \mathrm{Al}_{1.090}(\mathrm{OH})_{8.490} \mathrm{Cl}_{0.780} \cdot 2.451 \mathrm{H}_{2} \mathrm{O}$ & 2.752 \\
0.066 & $\mathrm{Mg}_{2.801} \mathrm{Fe}_{0.199} \mathrm{Al}_{1.013}(\mathrm{OH})_{7.723} \mathrm{Cl}_{1.315} \cdot 3.97 \mathrm{H}_{2} \mathrm{O}$ & 2.962 \\
0.096 & $\mathrm{Mg}_{2.713} \mathrm{Fe}_{0.287} \mathrm{Al}_{1.116}(\mathrm{OH})_{8.731} \mathrm{Cl}_{0.617} \cdot 2.475 \mathrm{H}_{2} \mathrm{O}$ & 2.688 \\
0.132 & $\mathrm{Mg}_{2.604} \mathrm{Fe}_{0.396} \mathrm{Al}_{0.959}(\mathrm{OH})_{7.696} \mathrm{Cl}_{1.181} \cdot 2.595 \mathrm{H}_{2} \mathrm{O}$ & 3.128 \\
\hline
\end{tabular}

Table 4. Stoichiometric formulae of hydrotalcite solids synthesized at $25,40,45,50,55$ and $60^{\circ} \mathrm{C}$ and $\mathrm{pH}=10.00 \pm 0.05$.

\begin{tabular}{|c|c|c|}
\hline $\begin{array}{l}T \\
\left({ }^{\circ} \mathrm{C}\right)\end{array}$ & Stoichiometric formulae & $\begin{array}{l}\left(\mathrm{Mg}^{2+} / \mathrm{Al}^{3+}\right) \\
\text { in solid phase }\end{array}$ \\
\hline 25 & $\mathrm{Mg}_{3} \mathrm{Al}_{1.085}(\mathrm{OH})_{8.481} \mathrm{Cl}_{0.774} \cdot 2.489 \mathrm{H}_{2} \mathrm{O}$ & 2.765 \\
\hline 40 & $\mathrm{Mg}_{3} \mathrm{Al}_{1.017}(\mathrm{OH})_{8.303} \mathrm{Cl}_{0.748} \cdot 2.309 \mathrm{H}_{2} \mathrm{O}$ & 2.950 \\
\hline 45 & $\mathrm{Mg}_{3} \mathrm{Al}_{1.034}(\mathrm{OH})_{8.393} \mathrm{Cl}_{0.709} \cdot 2.294 \mathrm{H}_{2} \mathrm{O}$ & 2.901 \\
\hline 50 & $\mathrm{Mg}_{3} \mathrm{Al}_{1.048}(\mathrm{OH})_{8.626} \mathrm{Cl}_{0.518} \cdot 2.630 \mathrm{H}_{2} \mathrm{O}$ & 2.863 \\
\hline 55 & $\mathrm{Mg}_{3} \mathrm{Al}_{1.042}(\mathrm{OH})_{8.463} \mathrm{Cl}_{0.663} \cdot 2.313 \mathrm{H}_{2} \mathrm{O}$ & 2.879 \\
\hline 60 & $\mathrm{Mg}_{3} \mathrm{Al}_{1.047}(\mathrm{OH})_{8.629} \mathrm{Cl}_{0.512} \cdot 2.367 \mathrm{H}_{2} \mathrm{O}$ & 2.865 \\
\hline
\end{tabular}

Tables 3 and 4 reveal the average $\left(\mathrm{Mg}^{2+}+\mathrm{Fe}^{2+}\right) / \mathrm{Al}^{3+}$ ratio in the solids to be $2.890 \pm 0.119$. Analyses of hydroxide and chloride are quite constant throughout the whole range of iron mole fractions in solids from 0.00 to 0.13 as well as for hydrotalcite phases synthesized at different temperatures. It was found that each formula unit contains $8.324 \pm 0.361 \mathrm{OH}^{-}$and $0.795 \pm 0.268 \mathrm{Cl}^{-}$. In addition, we observed that washed solids contained only traces of $\mathrm{Na}$ (about 1 wt. \%), which means that the stoichiometric coefficient of sodium in synthesized solids was less than $\mathrm{Na}_{0.001}$.

Measured concentrations of dissolved $\mathrm{Mg}$ and $\mathrm{Al}$ in experiments at $25^{\circ} \mathrm{C}$ vary over the range from 29.50 to $666.00 \mu \mathrm{mol} / \mathrm{kg}$, and from 1.11 to $435.02 \mu \mathrm{mol} / \mathrm{kg}$. We observed that molalities of dissolved $\mathrm{Al}$ increase with the growth of iron mole fraction in solids (Table 1). The molalities of dissolved iron in these experiments were below the detection limit of ICP-OES method $(0.54 \mu \mathrm{mol} / \mathrm{kg})$. Therefore, for further modeling calculations and in order to determine chemical potentials of aqueous $\mathrm{Fe}^{2+}$ species using GEM-Selektor software, the total dissolved molalities of iron in these experiments were assumed to be equal $0.54 \mu \mathrm{mol} / \mathrm{kg}$. Chemical analyses of dissolved chloride and sodium demonstrated that $\mathrm{Cl}^{-}$and $\mathrm{Na}$ concentrations are constant (99.85-111.70 mmol/ $\mathrm{kg}$ and 89.23-98.02 mmol/ $\mathrm{kg}$, respectively). Results of hydrotalcite syntheses at higher temperatures demonstrated that concentrations of dissolved magnesium decrease (from 666.000 to $21.5 \mu \mathrm{mol} / \mathrm{kg}$ ) with the growth of temperature (from 25 to $60{ }^{\circ} \mathrm{C}$ ) (see Table 2). At the same time $\mathrm{Al}$ concentrations $(1.11-3.03 \mu \mathrm{mol} / \mathrm{kg})$ do not depend on temperature. Measured concentrations of chloride and sodium were determined on the level $92.23-122.42 \mathrm{mmol} / \mathrm{kg}$ and $90.16-100.25 \mathrm{mmol} / \mathrm{kg}$, respectively. In conclusion we see that the ionic strength ( $\sim 0.1 \mathrm{M})$ of all "synthesis solutions" is generally defined by sodium content and this fact permitted the use of the Davies model for estimating activities and chemical potentials of relevant dissolved components (i.e., $\mathrm{Mg}^{2+}, \mathrm{Fe}^{2+}, \mathrm{Al}^{3+}, \mathrm{OH}^{-}$, $\left.\mathrm{Cl}^{-}\right)$.

\subsection{Characterization of hydrotalcite-pyroaurite solids by PXRD, IR spectroscopy, TGA analyses, SEM and EDX techniques}

The PXRD technique was applied in order to prove that all precipitates are indeed pure hydrotalcite-pyroaurite phases and to check that hydrotalcite-pyroaurite compositions form a continuous solid solution series. We observed that precipitates with mole fractions of iron $x \mathrm{Fe}_{\text {solid }}=\mathrm{Fe}^{2+} /\left(\mathrm{Fe}^{2+}+\right.$ $\mathrm{Mg}^{2+}$ ) varying from 0.00 to 0.13 display diffraction patterns (Fig. 1) typical for pure hydrotalcite-like phases [26].

This means that the amounts of any conceivable crystalline impurities in the solids (such as, gibbsite, brucite and ferric oxides and hydroxides) do not exceed the detection limit of the PXRD technique (about 1-5 wt. \%) [27]. However, in precipitates with higher mole fraction of iron $\left(x \mathrm{Fe}_{\text {solid }}>0.13\right)$, we detected additional reflexes which were attributed to lepidocrocite [28], ferric hydrates [29] or goethite [30]. The presence of these substances can be explained by the partial oxidation of $\mathrm{Fe}$ (II) to $\mathrm{Fe}$ (III) during the preparation of samples. This is confirmed by numerous observations of very fast iron oxidation processes in similar Fe(II)- containing phases (called as "green rusts"), when in contact with air or another oxidizing agent green rust phases transform into magnetite, goethite $\alpha$ $\mathrm{FeOOH}$, lepidocrocite $\gamma$-FeOOH, akaganeite, or ferrihydrite $5 \mathrm{Fe}_{2} \mathrm{O}_{3} \cdot 9 \mathrm{H}_{2} \mathrm{O}$ [31-35]. It was concluded that the application of a glove-box with an argon atmosphere would allow us to exclude the oxidation of $\mathrm{Fe}$ (II) in the synthesized hydrotalcite-pyroaurite compositions. Unit-cell parameters of hydrotalcite-pyroaurite phases with $x \mathrm{Fe}_{\text {solid }}$ from 0.00 to 0.13 have been calculated using a Bragg-type evaluation according to the scheme described previously [20]. Evaluated unit-cell parameters $a_{\mathrm{o}}=b_{\mathrm{o}}$ and $c_{\mathrm{o}}$ (Table 5, Figs. 2 and 3) of hydrotalcite-pyroaurite solids synthesized at $25^{\circ} \mathrm{C}$ are represented as a function of mole fraction of iron.

As seen on Fig. 2, the unit-cell parameter $a_{0}=b_{0}$ correlates with the mole fraction of iron and was approximated by using the linear function (see dashed line in Fig. 2). More-

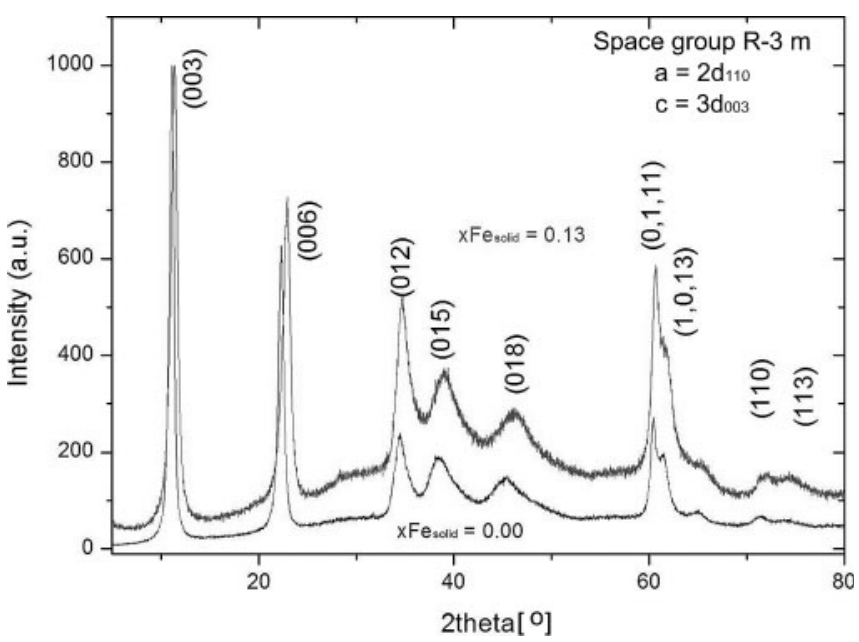

Fig. 1. X-ray diffractograms of synthetic hydrotalcite-pyroaurite solids with $x \mathrm{Fe}_{\text {solid }}=0.00$ and 0.13 . 
Table 5. Unit-cell parameters of synthesized hydrotalcite-pyroaurite solids synthesized at $25^{\circ} \mathrm{C}$ (the present study) and at $70{ }^{\circ} \mathrm{C}$ (Curtius et al., unpublished data) determined from Bragg evaluation and refined in the space group $R-3 \mathrm{~m}$.

\begin{tabular}{llcc}
\hline $\begin{array}{l}\text { Approximate } \\
\text { mole fraction } \\
\text { of iron solid }\end{array}$ & $a_{\mathrm{o}}=b_{\mathrm{o}}(\AA)$ & $c_{\mathrm{o}}(\AA)$ & Source \\
\hline 0.000 & & & \\
\hline 0.000 & $3.082 \pm 0.002$ & $24.065 \pm 0.010$ & $(1)$ \\
0.033 & $3.066 \pm 0.001$ & $23.959 \pm 0.006$ & $(2)$ \\
0.033 & $3.061 \pm 0.002$ & $23.783 \pm 0.010$ & $(1)$ \\
0.033 & $3.067 \pm 0.001$ & $23.951 \pm 0.006$ & $(2)$ \\
0.067 & $3.065 \pm 0.001$ & $23.779 \pm 0.006$ & $(2)$ \\
0.067 & $3.051 \pm 0.002$ & $23.591 \pm 0.010$ & $(1)$ \\
0.100 & $3.062 \pm 0.001$ & $23.612 \pm 0.006$ & $(2)$ \\
0.133 & $3.063 \pm 0.002$ & $23.351 \pm 0.010$ & $(1)$ \\
0.167 & $3.063 \pm 0.002$ & $23.286 \pm 0.010$ & $(1)$ \\
0.167 & $3.042 \pm 0.001$ & $23.011 \pm 0.006$ & $(2)$ \\
\hline
\end{tabular}

References: (1) - the present study, (2) - Curtius et al., unpublished data.

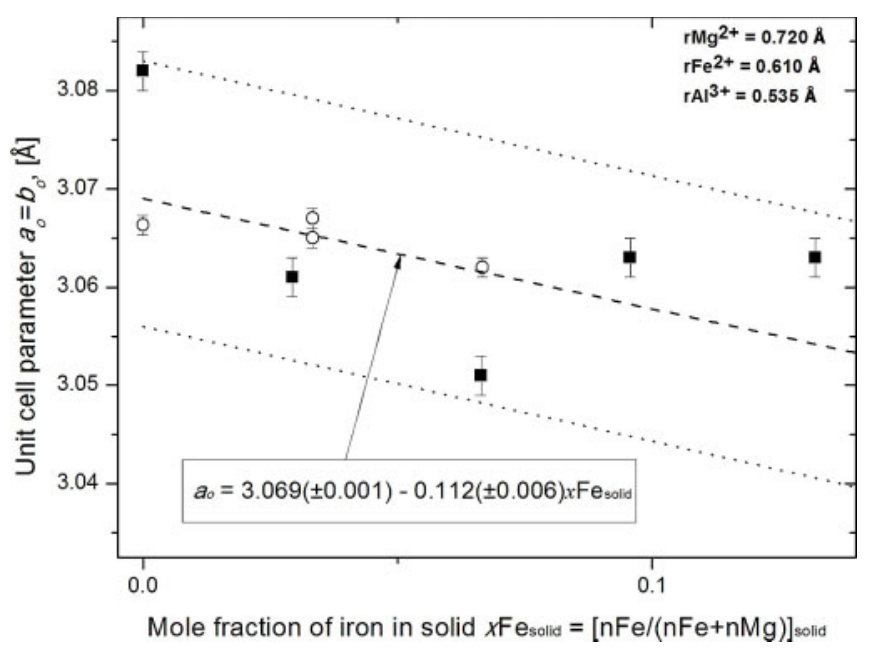

Fig. 2. Unit cell parameters $a_{\mathrm{o}}=b_{\mathrm{o}}$ as a function of the mole fraction of iron. The dashed line represents the linear approximation of experimental points. The dotted lines correspond to the theoretical curves based on a regular octahedral layer. Filled squares represent parameters determined from samples synthesized at $25^{\circ} \mathrm{C}$, open circles demonstrate unit cell parameters of solids synthesized at $70^{\circ} \mathrm{C}$ (Curtius et al., unpublished data).

over, we found that the theoretical dependence (see dotted curves) of unit-cell distance $a_{\mathrm{o}}=b_{\mathrm{o}}$ on the mole fractions of iron for an idealized octahedral layer (where ionic radii are $r_{\mathrm{Mg}^{2+}}=0.720 \AA, r_{\mathrm{Fe}^{2+}}=0.610 \AA, r_{A l^{3+}}=0.535 \AA$ [36]) has the same slope as the linear approximation. This can be explained by the fact that hydrotalcite-pyroaurite solids in the range $x \mathrm{Fe}_{\text {solid }}$ from 0.00 to 0.13 form continuous solid solution series and the variation of cell-parameter $a_{\mathrm{o}}=b_{\mathrm{o}}$ is in agreement with the Vegard's law [37].

On the other hand, the lattice parameter $c_{0}$ corresponds to three layer rhombohedral polytype $3 \mathrm{R}$ and is represented as a function of iron mole fraction shown in Fig. 3.

As seen on this plot, this unit-cell parameter $c_{\mathrm{o}}$ does not change significantly with increasing mole fraction of iron. The slight decrease (from 24.065 to $23.011 \AA$ ) can be attributed to the isostructural substitution of $\mathrm{Mg}^{2+}(0.720 \AA)$ by smaller $\mathrm{Fe}^{2+}(0.610 \AA)$.

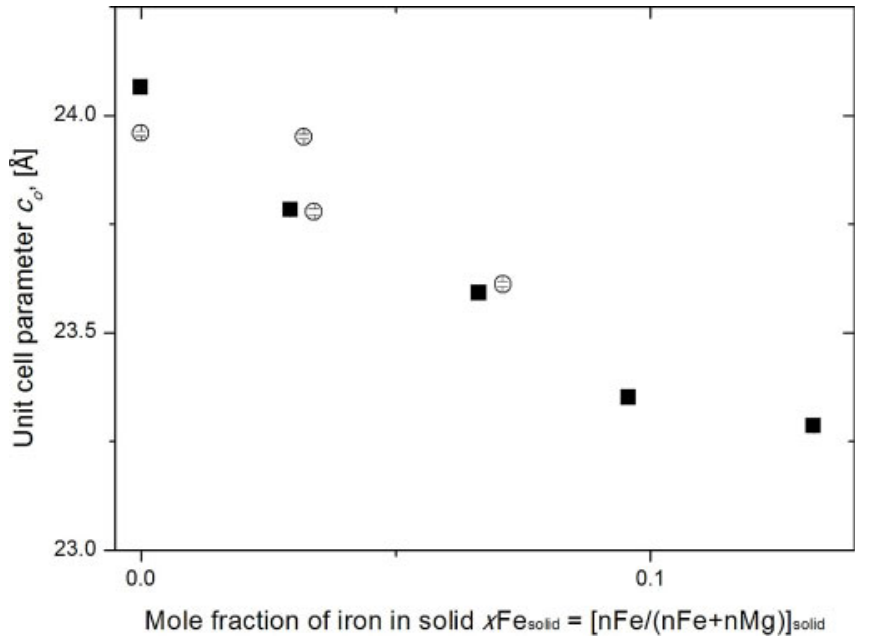

Fig. 3. Dependence of the unit cell parameter $c_{\mathrm{o}}$ on the mole fraction of Fe. Filled squares demonstrate results from samples synthesized at $25^{\circ} \mathrm{C}$, open circles represent unit cell parameters of solids synthesized at $70^{\circ} \mathrm{C}$ (Curtius et al., unpublished data).

Table 6. Unit-cell parameters of hydrotalcite solids synthesized at 25 , $40,45,50,55$ and $60^{\circ} \mathrm{C}$ and determined from Bragg evaluation and refined in the space group $R-3 \mathrm{~m}$.

\begin{tabular}{lccc}
\hline $\begin{array}{l}\left.\mathrm{Mg}^{2+} / \mathrm{Al}^{3+}\right) \\
\text { ratio in solid }\end{array}$ & $\begin{array}{c}\text { Temperature } \\
\left({ }^{\circ} \mathrm{C}\right)\end{array}$ & $\begin{array}{c}a_{\mathrm{o}}=b_{\mathrm{o}} \\
(\AA)\end{array}$ & $\begin{array}{c}c_{\mathrm{o}} \\
(\AA)\end{array}$ \\
\hline 2.912 & 25 & $3.082 \pm 0.002$ & $24.065 \pm 0.010$ \\
2.765 & 25 & $3.065 \pm 0.002$ & $23.863 \pm 0.010$ \\
2.950 & 40 & $3.086 \pm 0.002$ & $23.778 \pm 0.010$ \\
2.901 & 45 & $3.099 \pm 0.002$ & $23.784 \pm 0.010$ \\
2.863 & 50 & $3.090 \pm 0.002$ & $23.641 \pm 0.010$ \\
2.879 & 55 & $3.071 \pm 0.002$ & $23.860 \pm 0.010$ \\
2.865 & 60 & $3.100 \pm 0.002$ & $23.644 \pm 0.010$ \\
\hline
\end{tabular}

Unit-cell parameters of synthesized pure hydrotalcite $\left(x \mathrm{Fe}_{\text {solid }}=0\right)$ solids as a function of temperature of coprecipitation experiments are represented in Table 6. We observed that the measured unit-cell parameters $a_{\mathrm{o}}=b_{\mathrm{o}}$ and $c_{\text {o }}$ are remarkably constant $(3.085 \pm 0.013 \AA$ and $23.805 \pm$ $0.146 \AA$, respectively) in all synthesized hydrotalcites and do not deviate significantly with increasing temperature. The correlation between cationic $\left(\mathrm{Mg}^{2+} / \mathrm{Al}^{3+}\right)$ ratios in hydrotalcite solids and lattice parameters also was not observed. However, due to the difference of ionic radii of $\mathrm{Mg}^{2+}(0.720 \AA)$ and $\mathrm{Al}^{3+}(0.535 \AA)$ the increase of cationic $\left(\mathrm{Mg}^{2+} / \mathrm{Al}^{3+}\right)$ ratio should increase the intermetallic distances (i.e., $a_{\mathrm{o}}=b_{\mathrm{o}}$ parameters) in the hydrotalcite structure.

Infrared spectroscopic measurements have been performed to identify the nature of interlayer anions and to investigate its interaction with brucite-like layers. We found that IR spectra show very strong hydroxyl- and waterstretching bands at $3450 \mathrm{~cm}^{-1}$ and $1640 \mathrm{~cm}^{-1}$, respectively. Other strong bands at about $850 \mathrm{~cm}^{-1}$, were attributed to the translational movements of the oxygen in the octahedral brucite-like layers. The quite weak band due to adsorbed carbonate was detected at $1370 \mathrm{~cm}^{-1}$. The presence of carbonate in precipitates is explained by the very strong affinity of LDHs for this anion. We expect that carbonate was adsorbed during the preparation of the samples for IR analyses when $\mathrm{LDH}$ powders were mixed with $\mathrm{KBr}$ phase or even during the synthesis procedure. 


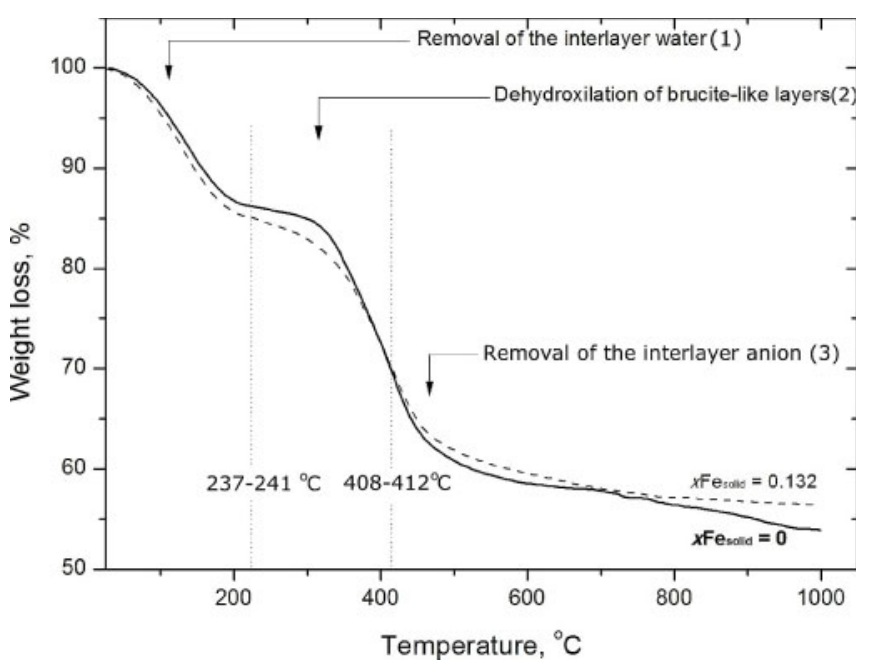

Fig. 4. TGA curves of solids with $x \mathrm{Fe}_{\text {solid }}=0.00$ (solid curve) and with $x \mathrm{Fe}_{\text {solid }}=0.132$ (dashed curve). The applied heating rate was $10{ }^{\circ} \mathrm{C} / \mathrm{min}$. Decomposition steps are shown according to (Rives, 2002).

Thermogravimetric analyses together with coupled differential scanning calorimetric measurements of synthesized hydrotalcite-pyroaurite series with mole fraction of iron from 0.00 to 0.13 demonstrated that thermal decomposition includes three main stages (Fig. 4).

These results are in agreement with the previous literature data [38-40] showing that thermal decomposition of layered double hydroxides takes place in three steps: (1) the removal of the interlayer water, (2) the decomposition of structural hydroxyl groups and finally (3) the loss of the interlayer anions. For the current compounds, these three decomposition steps were evaluated by determining the second derivative TGA-curve and confirmed by the results of DSC measurements. We demonstrated that: (1) the first endothermic peaks occur between room temperature and approximately $239^{\circ} \mathrm{C}$, with its maxima at $136{ }^{\circ} \mathrm{C}$ due to desorption of the interlayer water; (2) the second endothermic peaks between $239{ }^{\circ} \mathrm{C}$ and $410{ }^{\circ} \mathrm{C}$ indicate a partial dehy-

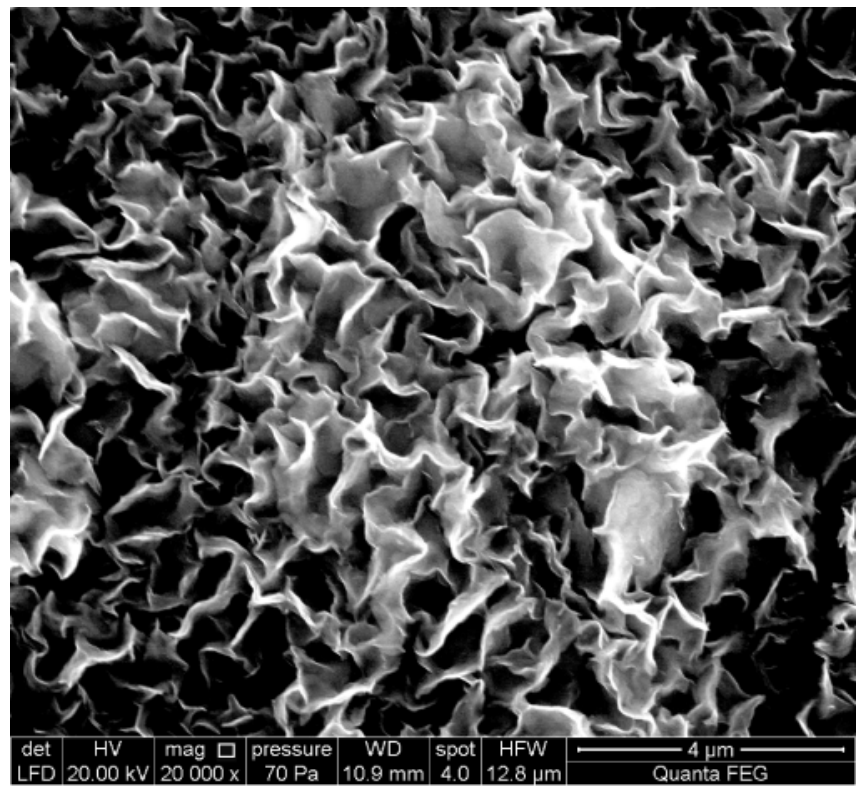

Fig. 5. Typical morphology of the Mg-Al-Fe-LDH precipitate $\left(x \mathrm{Fe}_{\text {soli }}\right.$ $=0.132)$, investigated by SEM. droxylation of brucite-like layer. The final (3) decomposition step from $410{ }^{\circ} \mathrm{C}$ to $1000{ }^{\circ} \mathrm{C}$ is recognized as loss of interlayer anions and formation of the mixture of $\mathrm{Mg}, \mathrm{Al}$ and $\mathrm{Fe}$ oxides. We found that the incorporation of divalent iron into the structure of solids does not strongly affect their thermal stability because we observed that an increase of the mole fraction of iron does not cause a significant effect on the temperatures of removal interlayer water, dehydroxylation and removal of interlayer anions.

Scanning electron microphotographs demonstrated that majority of precipitated samples were typical for LDHs "sand rose" aggregates [41] (Fig. 5). The most common morphologies of the particles were based on deformed hexagonal platelets, $1-20 \mu \mathrm{m}$ in size.

Using energy dispersive X-ray analyses of individual particles we investigated the elemental distribution and these results showed that in synthesized phases with $x \mathrm{Fe}_{\text {solid }}$ from 0 to 0.13 the distribution of $\mathrm{Mg}, \mathrm{Al}, \mathrm{Fe}, \mathrm{C}, \mathrm{O}$ and $\mathrm{Cl}$ components is generally homogeneous and no other phases were observed.

\subsection{Estimation of molar Gibbs free energies and standard entropies of hydrotalcite-pyroaurite solids}

The solids as described in Tables 3 and 4 precipitated from the solutions presented in Tables 1 and 2, respectively. In this study we neglected the possible effect of oversaturation and we assumed equilibrium between the precipitated solids and their corresponding "synthesis solutions". This allowed the calculation of the molar Gibbs free energies of precipitates by modeling compositions of liquids and calculating chemical potentials of relevant dissolved compounds using GEM-Selektor [22] as described in Sect. 3.1.

The estimated standard Gibbs free energies of hydrotalcite-pyroaurite phases as a function of iron mole fraction $x \mathrm{Fe}_{\text {solid }}=n \mathrm{Fe} /(n \mathrm{Fe}+n \mathrm{Mg})$ are demonstrated in Fig. 6. As seen in Fig. 6, there is a tendency of $G_{\mathrm{f}}^{\circ}(298)$ growth when the mole fraction in synthesized solids increases.

However, this dependence is not clear and in order to improve the situation we examined the dependence of molar

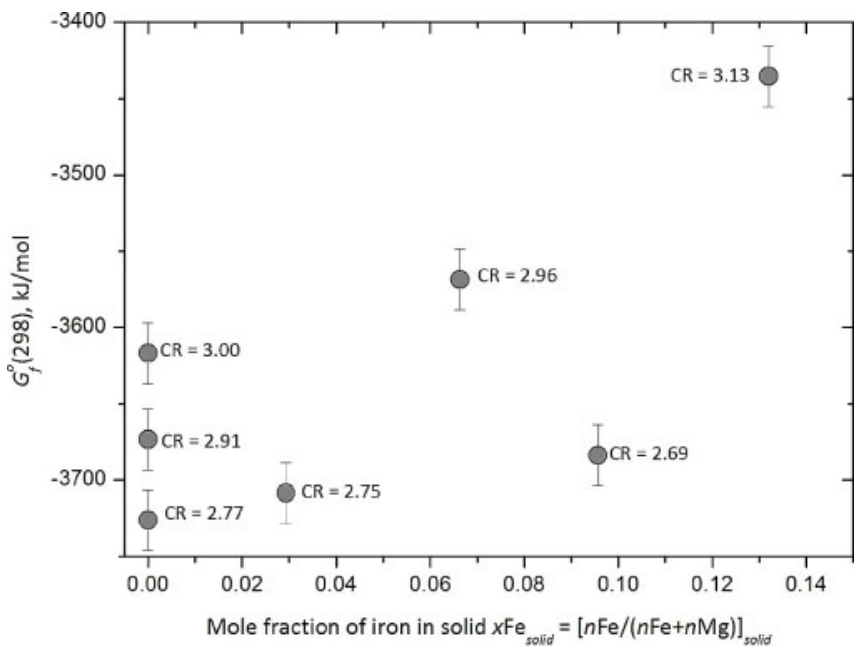

Fig. 6. Standard Gibbs free energies of "water-free" solids calculated as a function of the mole fraction of iron. 


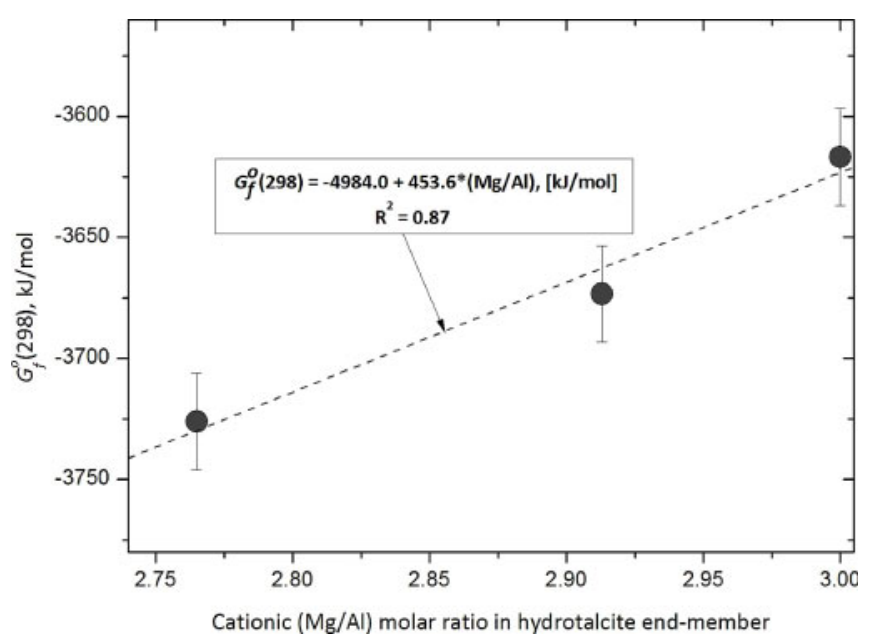

Fig. 7. Standard Gibbs free energies of "water-free" hydrotalcite solids represented as a function of $\mathrm{Mg} / \mathrm{Al}$ molar ratio.

Gibbs free energy on the $\mathrm{Mg} / \mathrm{Al}$ molar ratio in synthesized hydrotalcite phases (Fig. 7).

As seen on this plot, standard Gibbs free energies of hydrotalcite $\left(x \mathrm{Fe}_{\text {solid }}=0\right)$ can be represented as a linear function of the measured $\mathrm{Mg} / \mathrm{Al}$ cationic ratio. This linear dependence allowed us to extrapolate compositions of synthesized iron-containing compositions to the idealized $(\mathrm{Mg}+\mathrm{Fe}) / \mathrm{Al}=3 / 1$ stoichiometry and to obtain significantly improved linear relationship: $G_{\mathrm{f}}^{\circ}=(-3619.04 \pm$ $15.27)+(915.43 \pm 191.32) \cdot x \mathrm{Fe}_{\text {solid }}(\mathrm{kJ} / \mathrm{mol}), \quad R^{2}=0.98$ (Fig. 8), from which we determined the standard Gibbs free energies of end-members: $G_{\mathrm{f}}^{\circ}(\mathrm{Htlc})=-3619.04 \pm$ $15.27 \mathrm{~kJ} / \mathrm{mol} ; G_{\mathrm{f}}^{\circ}(\mathrm{Pyr})=-2703.61 \pm 191.93 \mathrm{~kJ} / \mathrm{mol}$.

This is in agreement with the $G_{\mathrm{f}}^{\circ}$ value for hydrotalcite from the study of Bravo-Suárez [42]. These authors determined a value of $-890.10 \pm 12.06 \mathrm{~kJ} / \mathrm{mol}$ for a "water-free" solid having the stoichiometry $\left[\mathrm{Mg}_{0.75} \mathrm{Al}_{0.25}(\mathrm{OH})_{2}\right]\left(\mathrm{Cl}_{0.25}\right)$. Normalizing this stoichiometry to three $\mathrm{Mg}$ (i.e., $\left.\mathrm{Mg}_{3} \mathrm{Al}_{1}(\mathrm{OH})_{8} \mathrm{Cl}_{1}\right)$ gives $-3560.40 \pm 48.25 \mathrm{~kJ} / \mathrm{mol}$. In order

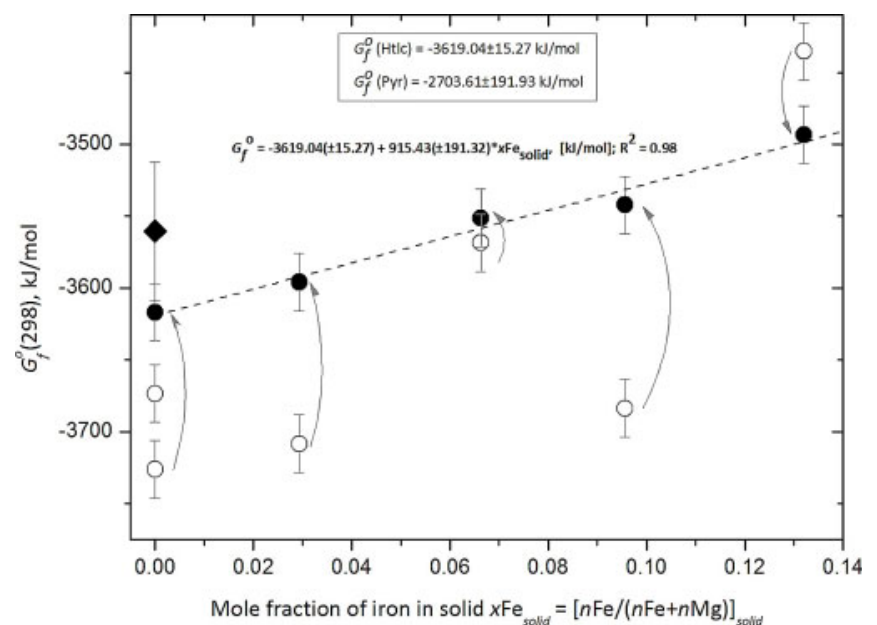

Fig. 8. Standard Gibbs free energies of hydrotalcite-pyroaurite solids calculated as mole fraction of iron. Open circles are calculated from actually analyzed stoichiometries of synthesized solids. Filled circles are results obtained from idealized $\left(\mathrm{Mg}_{1-x}, \mathrm{Fe}_{x}\right)_{3} \mathrm{Al}_{1}$ stoichiometries of hydrotalcite-pyroaurite solids (see text above). The diamond symbol represents a result from Bravo-Suárez et al., 2004 normalized to $\mathrm{Mg}_{3}$-stoichiometry. to assess the influence of the intercalated anions on the aqueous solubility of hydrotalcite-like solids we compared the standard Gibbs free energy of Cl-bearing hydrotalcite $(-3619.04 \pm 15.27 \mathrm{~kJ} / \mathrm{mol})$ obtained in the present study with data presented for $\mathrm{CO}_{3}$-containing hydrotalcite $(-3746.90 \pm 11.00 \mathrm{~kJ} / \mathrm{mol})$ [19]. The difference $127.86 \pm$ $18.82 \mathrm{~kJ} / \mathrm{mol}$ denotes the effect of the intercalated anion on the aqueous solubility, demonstrating that $\mathrm{Cl}^{-}$containing hydrotalcite have to be more soluble than the carbonate-bearing hydrotalcite. This conclusion confirms recent literature results of Allada et al., [8]. Based on calorimetric measurements these authors predicted equilibrium constants for the dissolution of $\mathrm{Cl}^{-}$and $\mathrm{CO}_{3}{ }^{2-}$ containing hydrotalcites and concluded that carbonate substances will be less soluble than solids bearing chloride anion.

To provide reasonable temperature and pressure corrections for the thermodynamic properties of the hydrotalcite end-member, we estimated the absolute molar entropy at $298 \mathrm{~K}$ and 1 bar. This has been done using the method of Helgeson and using results of hydrotalcite syntheses at variable $\left(25,40,45,50,55\right.$ and $60^{\circ} \mathrm{C}$ ) temperatures (see Sect. 3.2).

Applying the method of Helgeson we found that absolute entropy of hydrotalcite composition is equal to $318.40 \mathrm{~J} / \mathrm{mol} \mathrm{K}$. On the other hand, the second approach demonstrated that absolute entropy varies in the range from 558.93 to $1434.75 \mathrm{~J} / \mathrm{mol} \mathrm{K}$.

These significant discrepancies in estimates of standard molar entropy are demonstrated on the temperature dependence of Gibbs free energies of hydrotalcite end-member (Fig. 9).

Assuming that heat capacity of hydrotalcite is a constant over the temperature from 25 to $60{ }^{\circ} \mathrm{C}$, we were able to construct the theoretical dependence of Gibbs free energy on the

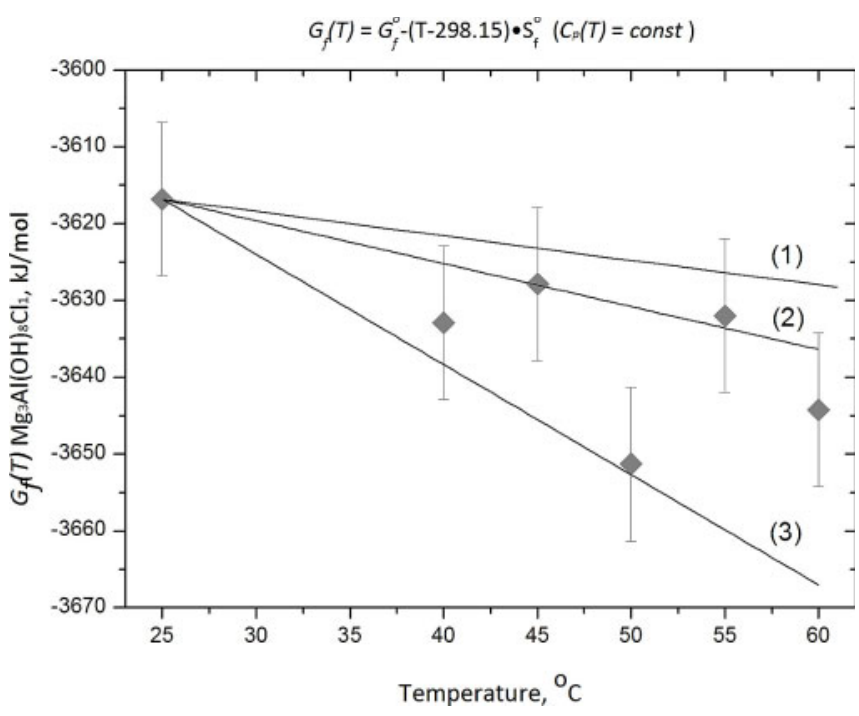

Fig. 9. Gibbs free energy of hydrotalcite end-member as a function of temperature. Diamond symbols correspond to results from coprecipitation experiments at different temperatures and using the idealized $\mathrm{Mg}_{3} \mathrm{Al}_{1}$-stoichiometry. Lines (1), (2), (3) show results obtained from temperature dependences of Gibbs free energies corresponding to Eq. (8) with absolute molar entropies are equal to $318.40,558.93$, $1434.75 \mathrm{~J} / \mathrm{mol} \mathrm{K}$, respectively. 
temperature from the following relation:

$$
G_{\mathrm{f}}(T)=G_{\mathrm{f}}^{\circ}-(T-298.15) \cdot S_{\mathrm{f}}^{\circ}
$$

From Fig. 9 it can be seen that all estimates of absolute molar entropies do not fit experimental results sufficiently well. For the possible further work in order to provide more accurate information about absolute molar entropies, we would recommend to perform calorimetric measurements. The providing data about absolute molar entropy of hydrotalcite solids by calorimetric measurements is the objective of our forthcoming separate study.

\section{Discussion and conclusions}

The aim of the present work was to investigate aqueous solubilities of the hydrotalcite-pyroaurite solids by using results of syntheses (by co-precipitation) experiments carried out at ambient conditions $\left(25^{\circ} \mathrm{C}, P=1\right.$ bar $)$ and at elevated temperatures $\left(40,45,50,55\right.$ and $\left.60^{\circ} \mathrm{C}\right)$. Hydrotalcitepyroaurite solids with different iron mole fractions $x \mathrm{Fe}_{\text {solid }}=$ $\mathrm{Fe}^{2+} /\left(\mathrm{Mg}^{2+}+\mathrm{Fe}^{2+}\right)$ varying from 0 to 0.13 have been successfully synthesized. The $\left(\mathrm{Mg}^{2+}+\mathrm{Fe}^{2+}\right) / \mathrm{Al}^{3+}$ ratios of these precipitates were kept constant at $2.890 \pm 0.119$. All PXRD patterns of these solids indicated the formation of a single phase belonging to the hydrotalcite-pyroaurite solid solution series [26]. However, products of syntheses with iron mole fraction higher than 0.13 display additional PXRD reflexes attributed to the mixture of Fe oxides and hydroxides (for instance, lepidocrocite, ferric hydrates or goethite) [28-30]. Formation of these phases was explained by very fast oxidation of hydrotalcite-pyroaurite solids in contact with air or other oxidizing agent during the preparation (or during PXRD measurements) of samples.

The thermal behavior of samples with $0 \leq x \mathrm{Fe}_{\text {solid }} \leq 0.13$ is that expected for LDH with 3 main decomposition steps (removal of interlayer water, dehydroxylation of brucitelike layers and removal of interlayer anion). Temperatures of these three events do not depend on the content of iron in solids. TGA-DSC measurements were used here successfully for measuring the water, hydroxyl and chloridecontent. For hydrotalcite-like phases this is usually difficult to achieve because the three decomposition steps are often not well separated.

Infrared spectra of synthesized solids show strong hydroxyl- and water-stretching bands at $3450 \mathrm{~cm}^{-1}$ and $1640 \mathrm{~cm}^{-1}$, respectively. The strong bands at about $850 \mathrm{~cm}^{-1}$ have been attributed to the translational movements of the oxygen in the octahedral brucite-like layers. The quite weak band at $1370 \mathrm{~cm}^{-1}$ was attributed to adsorbed traces of carbonate ions. We explained the presence of carbonate in precipitates by very strong affinity of hydrotalcite-like solids to this anion.

An extended aim of the present study included quantifying the standard Gibbs free energies and absolute molar entropies of hydrotalcite-pyroaurite compositions. These aims can be achieved by analyzing solution- and solid compositions and assuming that thermodynamic equilibrium between precipitated solid and mother solution was reached. All chemical analyses have been performed by using ICP-OES, photometric, EDX and TGA techniques and the results of thermodynamic calculations are described in Sect. 4.3.

We demonstrated that the estimated values of standard Gibbs free energies correlate strongly with the stoichiometry of hydrotalcite-pyroaurite solids. Firstly, we observed that values of molar Gibbs free energies are related with $\mathrm{Me}^{2+} / \mathrm{Me}^{3+}$ cationic ratio. In fact, the growth of $\mathrm{Mg}^{2+} / \mathrm{Al}^{3+}$ ratio from 2.77 to 3.00 in hydrotalcite endmember results in increase of Gibbs free energy value from -3673.37 to $-3619.04 \mathrm{~kJ} / \mathrm{mol}$. This observation permitted to normalize all estimates of $G_{\mathrm{f}}^{\circ}$ with respect to idealized hydrotalcite-pyroaurite compositions with cationic ratio $\left(\mathrm{Mg}^{2+}+\mathrm{Fe}^{2+}\right) / \mathrm{Al}^{3+}=3: 1$ and $0<x \mathrm{Fe}_{\text {solid }} \leq 0.13$. As a result, we observed that the estimates of standard Gibbs free energy follows the linear function of iron mole fraction and, therefore, yields the following first estimates: $-3619.04 \pm$ 15.27 and $-2703.61 \pm 191.93 \mathrm{~kJ} / \mathrm{mol}$ for Htlc and Pyr endmembers, respectively.

Applying Helgeson's method [25] and results of hydrotalcite syntheses at elevated $\left(40,4550,55\right.$ and $\left.60{ }^{\circ} \mathrm{C}\right)$ temperatures we obtained absolute molar entropy estimates for hydrotalcite end-member. It was recognized that two approaches do not fit experimental results sufficiently well and these clearly seems the need to perform more precise calorimetric measurements. Particularly, it is expected that such a method will be appropriate for a more detailed comparison of stability properties of $\mathrm{CO}_{3}{ }^{2-}$ - and $\mathrm{Cl}^{-}$bearing LDHs and, finally, for specifying the effect of intercalated anion on the aqueous solubilities of hydrotalcite-like solids. At the present state of the investigation we were not able to perform thermodynamic and solubility modeling of hydrotalcite-pyroaurite system from point of view of solid solution concept due to the missing information about: 1) the existence of hydrotalcite-pyroaurite phases with $x \mathrm{Fe}_{\text {solid }}>$ 0.13 and, especially, pyroaurite end-member, and 2) the degree of oversaturation in "synthesis solutions". Because of this, we believe that further co-precipitation experiments as well as dissolution studies with synthesized solids will provide more results, extending the knowledge about the behavior of hydrotalcite-pyroaurite system in aqueous environment, i.e., particularly, at conditions of nuclear waste repositories.

Acknowledgment. We thank Hartmut Schlenz, Stephan Schmitz for their help with PXRD; Andrey Bukaemskiy, Martina Klinkenberg, Sabrina Labs - for their support with SEM/EDX measurements; Giuseppe Modolo - for performing the TGA-DSC measurements; Zaina Paparigas, Gabriele Kaiser - for guidance and support in the lab.

\section{References}

1. Aramendia, M. A., Borau, V., Jimenez, U., Marinas, J. M., Ruiz Jr., Urbano, F. J.: Comparative study of $\mathrm{Mg} / \mathrm{M}(\mathrm{III})(\mathrm{M}=\mathrm{Al}, \mathrm{Ga}, \mathrm{In})$ layered double hydroxides obtained by co-precipitation and the sol-gel method. J. Solid State Chem. 168(1), 156-161 (2002).

2. Boclair, J. W., Braterman, P. S., Jiang, J. P., Lou, S. W., Yarberry, F.: Layered double hydroxide stability. 2. Formation of $\mathrm{Cr}(\mathrm{III})$ containing layered double hydroxides directly from solution. Chem. Mater. 11(2), 303-307 (1999).

3. Carteret, C., Gregoire, B., Ruby, C.: Tunable composition of $\mathrm{Ni}(\mathrm{II})-\mathrm{Al}(\mathrm{III})$ and $\mathrm{Ni}(\mathrm{II})-\mathrm{Fe}(\mathrm{III})$ layered hydroxides within a wide range of layer charge. Solid State Sc. 13(1), 146-150 (2011). 
4. Curtius, H., Ufer, K., Dardenne, K.: Preparation and characterization of $\mathrm{Zr}$-IV-containing $\mathrm{Mg}-\mathrm{Al}-\mathrm{Cl}$ layered double hydroxide. Radiochim. Acta 97(8), 423-428 (2009).

5. Rousselot, I., Taviot-Gueho, C., Leroux, F., Leone, P., Palvadeau, P., Besse, J. P.: Insights on the structural chemistry of hydrocalumite and hydrotalcite-like materials: Investigation of the series $\mathrm{Ca}_{2} \mathrm{M}^{3+}(\mathrm{OH})_{6} \mathrm{Cl} \cdot 2 \mathrm{H}_{2} \mathrm{O}\left(\mathrm{M}^{3+}: \mathrm{Al}^{3+}, \mathrm{Ga}^{3+}, \mathrm{Fe}^{3+}\right.$, and $\left.\mathrm{Sc}^{3+}\right)$ by X-ray powder diffraction. J. Solid State Chem. 167(1), 137144 (2002).

6. Ulibarri, M. A., Cornejo, J., Hernandez, M. J.: Effects of hydrothermal treatment on textural properties of $\left[\mathrm{Al}_{2} \mathrm{Li}(\mathrm{OH})_{6}\right]_{2} \mathrm{CO}_{3}$. $n \mathrm{H}_{2}$ O. J. Mater. Sci. 22(4), 1168-1172 (1987).

7. Wang, J. D., Serrette, G., Tian, Y., Clearfield, A.: Synthetic and catalytic studies of inorganically pillared and organically pillared layered double hydroxides. Appl. Clay Sci. 10(1-2), 103-115 (1995).

8. Allada, R. K., Pless, J. D., Nenoff, T. M., Navrotsky, A.: Thermochemistry of hydrotalcite-like phases intercalated with $\mathrm{CO}_{3}{ }^{2-}$, $\mathrm{NO}_{3}{ }^{-}, \mathrm{Cl}^{-}, \mathrm{I}^{-}$, and $\mathrm{ReO}_{4}{ }^{-}$. Chem. Mater. 17(9), 2455-2459 (2005).

9. Brindley, G. W., Kikkawa, S.: Thermal-behavior of hydrotalcite and of anion-exchanged forms of hydrotalcite. Clays Clay Mineral. 28(2), 87-91 (1980).

10. Carlino, S.: The intercalation of carboxylic acids into layered double hydroxides: A critical evaluation and review of the different methods. Solid State Ion. 98(1-2), 73-84 (1997).

11. Carrado, K. A., Kostapapas, A., Suib, S. L.: Layered double hydroxides (LDHs). Solid State Ion. 26(2), 77-86 (1988).

12. Chibwe, K., Jones, W.: Intercalation of organic and inorganic anions into layered double hydroxides. J. Chem. Soc.-Chem. Commun. (14), 926-927 (1989).

13. Chisem, I. C., Jones, W.: Ion-exchange properties of lithium aluminum layered double hydroxides. J. Mater. Chem. 4(11), 17371744 (1994).

14. Miyata, S., Kumura, T.: Synthesis of new hydrotalcite-like compounds and their physicochemical properties. Chem. Lett. 8, 843848 (1973).

15. Newman, S. P., Jones, W.: Synthesis, characterization and applications of layered double hydroxides containing organic guests. New J. Chem. 22(6), 649 (1998).

16. NAGRA TECHNICAL REPORT 02-05: Project Opalinus Clay. Demonstration of disposal feasibility for spent fuel, vitrified high-level waste and long-lived intermediate-level waste (Entsorgungsnachweis), NAGRA: Wettingen 2002.

17. Allada, R. K., Navrotsky, A., Berbeco, H. T., Casey, W. H.: Thermochemistry and aqueous solubilities of hydrotalcite-like solids. Science 296(5568), 721-723 (2002).

18. Johnson, C. A., Glasser, F. P.: Hydrotalcite-like minerals $\left(\mathrm{M}_{2} \mathrm{Al}(\mathrm{OH})_{6}\left(\mathrm{CO}_{3}\right)_{0.5} \cdot x \mathrm{H}_{2} \mathrm{O}\right.$, where $\left.\mathrm{M}=\mathrm{Mg}, \mathrm{Zn}, \mathrm{Co}, \mathrm{Ni}\right)$ in the environment: synthesis, characterization and thermodynamic stability. Clays Clay Mineral. 51(1), 1-8 (2003).

19. Rozov, K., Berner, U., Kulik, D., Diamond, L. W.: Solubility and thermodynamic properties of carbonate-bearing hydrotalcitepyroaurite solid solutions with $3: 1 \mathrm{Mg} /(\mathrm{Al}+\mathrm{Fe})$ mole ratio. Clays Clay Mineral. 59(3), 215-232 (2011).

20. Rozov, K., Berner, U., Taviot-Gueho, C., Leroux, F., Renaudin, G., Kulik, D, Diamond, L. W. : Synthesis and characterization of the LDH hydrotalcite-pyroaurite solid-solution series. Cement Concrete Res. 40(8), 1248-1254 (2010).

21. Mazeina, L., Curtius, H., Fachinger, J., Odoj, R.: Characterization of secondary products of uranium-aluminum material test reactor fuel element corrosion in repository-relevant brine. J. Nucl. Mater. 323(1), 1-7 (2003).

22. Kulik, D., GEM-Selektor. Research package for thermodynamic modeling of aquatic (geo)chemical systems by Gibbs Energy Minimization (GEM). http://gems.web.psi.ch.
23. Hummel, W., Berner, U., Curti, E., Pearson, F. J., Thoenen, T.: Nagra/PSI chemical thermodynamic data base $01 / 01$. Radiochim. Acta 90(9-11), 805-813 (2002).

24. Shock, E. L., Sassani, D. C., Willis, M., Sverjensky, D. A.: Inorganic species in geologic fluids: Correlations among standard molar thermodynamic properties of aqueous ions and hydroxide complexes. Geochim. Cosmochim. Acta 61(5), 907-950 (1997).

25. Helgeson, H. C., Delany, J. M., Nesbitt, H. W., Bird, D. K.: Summary and critique of the thermodynamic properties of rockforming minerals. Am. J. Sci. 278, 1-229 (1978).

26. Malherbe, F., Besse, J. P.: Investigating the effects of guest-host interactions on the properties of anion-exchanged Mg-Al hydrotalcites. J. Solid State Chem. 155(2), 332-341 (2000).

27. Lanfranco, A. M., Schofield, P. F., Murphy, P. J., Hodson, M. E., Mosselmans, J. F. W., Valsami-Jones, E.: Characterization and identification of mixed-metal phosphates in soils: the application, of Raman spectroscopy. Mineral. Mag. 67(6), 1299-1316 (2003).

28. Eggleton, R. A., Fitzpatrick, R. W.: New data and a revised structural model for ferrihydrite. Clays Clay Mineral. 36(2), 111-124 (1988).

29. Chandy, K. C.: Thermal transformation of beta-ferric oxyhydroxide. Mineral. Mag. J. Mineral. Soc. 35(272), 666 (1965).

30. Van der Giessen, A. A.: The structure of iron (III) oxide-hydrate gels. J. Inorg. Nucl. Chem. 28(10), 2155-2159 (1966).

31. Christiansen, B. C., Balic-Zunic, T., Petit, P. O., Frandsen, C., Morup, S., Geckeis, H., Katerinopoulou, A., Stipp, S. L. S.: Composition and structure of an iron-bearing, layered double hydroxide (LDH) - Green rust sodium sulphate. Geochim. Cosmochim. Acta 74(18), 5424-5425 (2010).

32. Genin, J. M. R., Ruby, C., Upadhyay, C.: Structure and thermodynamics of ferrous, stoichiometric and ferric oxyhydroxycarbonate green rusts; redox flexibility and fougerite mineral. Solid State Sci. 8(11), 1330-1343 (2006).

33. Hansen, H. C. B., Borggaard, O. K., Sorensen, J.: Evaluation of the free-energy of formation of $\mathrm{Fe}(\mathrm{II})-\mathrm{Fe}(\mathrm{III})$ hydroxide-sulfate (green rust) and its reduction of nitrite. Geochim. Cosmochim. Acta 58(12), 2599-2608 (1994).

34. Refait, P., Genin, J. M. R.: The mechanisms of oxidation of ferrous hydroxychloride $\beta$ - $\mathrm{Fe}_{2}(\mathrm{OH})_{3} \mathrm{Cl}$ in aqueous solution: the formation of akaganeite vs. goethite. Corros. Sci. 39(3), 539-553 (1997).

35. Schwertmann, U., Fechter, H.: The formation of green rust and its transformation to lepidocrocite. Clay Miner, 29(1), 87-92 (1994).

36. Shannon, R. D.: Revised effective ionic-radii and systematic studies of interatomic distances in halides and chalcogenides. Acta Cryst. A 32, 751-767 (1976).

37. Danton, A. R., Ashcroft, N. W.: Vegard's law. Phys. Rev. A 13(6), 3161-3164 (1991).

38. Miyata, S.: Physicochemical properties of synthetic hydrotalcites in relation to composition. Clays Clay Mineral. 28(1), 50-56 (1980).

39. Frost, R. L., Vagvolgyi, V., Palmer, S. J., Kristof, J., Horvath, E.: Mechanism for hydrotalcite decomposition: A controlled rate thermal analysis study. J. Colloid Interf. Sci. 318(2), 302-308 (2008).

40. Rives, V.: Characterization of layered double hydroxides and their decomposition products. Mater. Chem. Phys. 75(1-3), 19-25 (2002).

41. Mistra, C., Perrota, J.: Composition and properties of synthetic hydrotalcites. Clays Clay Minerals 40, 45-150 (1992).

42. Bravo-Suarez, J. J., Paez-Mozo, E. A., Oyama, S. T.: Models for the estimation of thermodynamic properties of layered double hydroxides: Application to the study of their anion exchange characteristics. Quimica Nova 27(4), 574-581 (2004). 